\title{
Personalizing Class Conflict Across the Tasman: the New Zealand Great Strike and Trans-Tasman Biography
}

\author{
MELANIE NOLAN
}

$\mathrm{H}$ is Harry Holland's nibs fighting Billy Hughes, Harry lashes "Labor" fibs in the red "Reviews!"

Holland's pen is like a lance tipped with boiling gall!

He is making Billy's chance very black and small!

With determination, grim, Holland's fought for years!

Prison cannot silence him, nor can bribes or fears.

Josiah Cocking on Harry Holland and Billy Hughes, $1910{ }^{1}$

\begin{abstract}
This is a revisionist account of the New Zealand 1913 Great Strike, placing it in a trans-Tasman framework rather than, as is more usual, local and international contexts. It uses the bitter relationship between Harry Holland and Billy Hughes to personalize and dramatize the wider dynamic between the New Zealand and Australian labour movements around 1913. It contests the view that that the Tasman world was dying or that New Zealanders' resented 'Australian intervention' in the strike. Affective bonds which did not always match trading partnerships indicate the closeness of New Zealand and Australia peoples as indicated by a range of measures such as population exchange, the exchange of parcels in the mail and the strong push for transTasman union and socialist federation. The effect of the 1913 Great Strike followed closely by the war was, however, to destroy the dream of a trans- Tasman 'One Big Union'.
\end{abstract}

\section{Introduction: Trans-Tasman Revisionism}

The 1913 Great Strike was one of the most turbulent and violent industrial disputes in New Zealand's history: there were extraordinary scenes on Wellington's streets with the military facing strikers and their supporters with naked bayonets and machine guns. It compels our attention. Once relatively neglected, the story of the Great Strike of 1913 is now well researched. Erik Olssen led the way with his 1988 book on the militant industrial unions, the New Zealand Federation of Labor (FOL), known as the "Red Feds." 2 A dedicated collection of essays, Revolution: The 1913 Great Strike in New Zealand (2005), that developed out of a Trade Union History Project (TUHP) conference in November 2003 to commemorate the 90th anniversary of the 1913 strike, included accounts from police, history of crime, women's, media, British and US perspectives. ${ }^{3}$ Overall, the collection placed New Zealand's Great Strike in both its local and international contexts. The Museum of City and Sea hosted a photographic exhibition, "1913 Strike - War on the Wharves," in 2006 and, in association with the Labour History Project (as the TUHP has been renamed), a walk around Wellington's "1913 sites of struggle" in 2013, and a series of eight talks and events for the centenary of the 1913 strike. ${ }^{4}$ The latter included Pākeha conceptions about Māori industrial activism and the strike remembered in popular songs. ${ }^{5}$ Contemporary unionists contemplated the meaning of the 1913 strike and there was a commemorative parade through Wellington streets on 5 November 2013.6 There are now a range of accounts and a broad understanding in the community of the 1913 Great Strike. ${ }^{7}$

Journal of New Zealand Studies NS18 (2014), 118-136 
In this paper I consider 1913 yet again and argue that, despite recent work on the Great Strike, its significance and meaning for trans-Tasman relations, remains under-explored. This revisionist account places the strike, moreover, in its trans-Tasman framework from the perspective of biography. ${ }^{8}$ The key subjects in this narrative are William Morris (Billy) Hughes (1862-1952) and Henry Edmund (Harry) Holland (1868-1933), the former an Australian who led the Australian Labor Party (ALP) in power and was central in the labour split over conscription in 1916, and the latter an Australian who led the New Zealand Labour Party (NZLP) from 1919 to greater unity than it had ever attained by the time he died in $1933 .{ }^{9}$ Before 1913 these two socialists knew and disliked each other. Their relationship is not causal but it embodies wider connections and discontinuities in the Tasman world.

\section{Historiography and the Trans-Tasman Parcel Exchange}

Most regard the Great Strike of 1913 as one of the seminal events that led to the formation of the NZLP in 1916. The excesses of the Massey Government, particularly its use of special constables or "Massey's Cossacks" helped to unite the various labour factions into one party during the war. Leaders of the 1913 strikes - including Holland, Michael Joseph Savage and Peter Fraser - learned the hard lesson that the labour movement could not achieve its goals through industrial action alone. The strikers were defeated but, as Fraser reckoned, the militants might lose every battle but they were winning the campaign. ${ }^{10}$ When the NZLP was formed in 1916 the party united, and the militants went on to become political leaders then brokers in power in 1935. Such insights form the core of interpretations by Bill Sutch, Keith Sinclair and Barry Gustafson. ${ }^{11}$ Indeed W. H. (Bill) Oliver has characterized this most broadly as the left-wing interpretation of New Zealand history. ${ }^{12}$

On the other hand, there are more global accounts that narrate a broader economic and structural story. Events such as the 1913 Great Strike in New Zealand and the 1912 Brisbane General Strike are part of a world-wide phenomenon. ${ }^{13}$ One can focus on the unique or "exceptional" aspects but there was a general pattern, too. In a number of works Edward Shorter, Charles Tilly and Leonard Haimson sought to explain why there were waves of strikes internationally in the late nineteenth and early twentieth centuries. They considered a "giant rock of strike statistics," 110,000 of them, and how the nature of these disputes developed over half a century. They linked the growing number and intensity of the strikes to the process of industrialization resulting in social breakdown which, in turn, led to protests such as strikes. ${ }^{14}$ Did employers attempt to overpower unions, and thus incite strikes? Or were industrial workers encouraged to engage in strikes as a form of bargaining or power struggle so as to protect or expand their interests? Shorter, Tilly and Haimson tended to the latter view and interpreted French strikes as essentially political. Of course, the political and economic stories are not mutually exclusive; indeed, Olssen and others have emphasized local politics based on the international phenomena involving a struggle in the workplace.

The 1913 Great Strike was also an episode in trans-Tasman history. The trans-Tasman labour market underwrote the regional aspect. ${ }^{15}$ There was a wave of 45,000 Australians crossing the Tasman to New Zealand between 1861 and 1865 for gold. The "perennial exchange" saw a wave flow the other way in the 1880 s when New Zealand was in depression. A bigger wave between 1890 and 1910 (60,000) crossed to New Zealand escaping the federation drought and the ironbark economy that followed it. Not all settled: In 1911 there were 31,900 New Zealand-born in Australia and 50,000 Australian-born in New Zealand, the latter unprecedented in terms of proportions. ${ }^{16}$ There were patterns within this flow, particularly trans-Tasman labour circuits of 
shearers, seamen and miners. Within these circuits was a group of Australian unionists disillusioned with the Australian labour movement. Some of these were blacklisted, a group who punched above their numbers in political influence and who have been well researched. ${ }^{17}$ And yet the emphasis on the internationalism of industrial socialism means that British and US influences are considered equally as potent as Australian influences.

Part of the reason is that the trans-Tasman population exchange has not been measured or calibrated comparatively. ${ }^{18}$ Trade statistics are often used to indicate national connections. The direction of New Zealand exports to Australia dropped from over 60 percent in 1861 to about 10 percent by World War One, with similar movements in proportions of imports. ${ }^{19}$ So the transTasman connections are held to be in decline. The majority of New Zealand's trade for nearly a century until the 1960s was with the United Kingdom. In trade terms New Zealand and Britain were close. British trade and cultural links underlie James Belich's "re-colonization" arguments. ${ }^{20}$

We can examine other kinds of connections to indicate affective bonds, however, which did not always match trading partnerships. Rollo Arnold considered the permanent migration between the two countries (with a tide of Australian-born to New Zealand 1892 to 1909), the volume of passenger traffic between New Zealand and Australia (which showed a steadily increasing traffic up to 1911) and the rising proportion of Australian newspapers "taken" in New Zealand. ${ }^{21}$ Historians, including Patrick O'Farrell for the Irish in Australia and Charlotte Erickson for the "invisible" English and Scottish in the United States, have emphasized the importance of "mail" or correspondence. ${ }^{22}$ New Zealand and Australian mail was not disaggregated by country of destination; however, parcels were. The New Zealand Official Year Books show that the overwhelming proportion of parcels received in mail to New Zealand arrived from the United Kingdom, 73 percent in 1911. Australia is next "closest" with 18.5 percent. The US became the third "closest" on this measure in 1900. However, who were New Zealanders sending parcels to? While nearly half went to the UK or other countries through London, (48 percent) about the same proportion went to Australia until World War One (see table 1).

Table 1: Parcels Exchanged Between (a) New Zealand and (b) the United Kingdom (UK), Australia (OZ) and the United States (USA), 1891-1939

\begin{tabular}{|c|c|r|r|r|r|r|r|r|}
\hline \multirow{2}{*}{ Year } & \multicolumn{9}{|l|}{ Parcels Received in NZ from: } & \multicolumn{3}{l|}{ Despatched from NZ to: } \\
\cline { 2 - 9 } & UK & OZ & USA & Total & UK & OZ & USA & \multicolumn{1}{c|}{ Total } \\
\hline 1891 & 17115 & 1852 & & & 3253 & 1564 & & \\
\hline 1892 & 13988 & 2656 & & 16654 & 2961 & 1575 & & 4536 \\
\hline 1893 & 13586 & 3892 & & 17543 & 2962 & 2272 & & 5269 \\
\hline 1894 & 13147 & 5337 & & 18567 & 3325 & 2970 & & 6547 \\
\hline 1895 & 13681 & 5656 & & 19454 & 3524 & 3604 & & 7298 \\
\hline 1896 & 13730 & 5960 & & 19909 & 3446 & 3877 & & 7522 \\
\hline 1897 & 15742 & 7736 & & 23698 & 4197 & 4136 & & 8670 \\
\hline 1898 & 17823 & 8817 & & 27044 & 4023 & 4091 & & 8541 \\
\hline 1899 & 19719 & 9907 & & 30207 & 4524 & 4389 & & 9576 \\
\hline 1900 & 21682 & 10704 & 922 & 34236 & 4690 & 4163 & 395 & 10916 \\
\hline 1901 & 24011 & 11233 & 3019 & 39951 & 5787 & 5070 & 833 & 13336 \\
\hline 1902 & 28881 & 13435 & 4123 & 47654 & 6225 & 6044 & 1085 & 14779 \\
\hline 1903 & 37652 & 15359 & 5024 & 59655 & 7575 & 7355 & 1286 & 17577 \\
\hline 1904 & 43808 & 16808 & 5310 & 67887 & 8552 & 9124 & 1321 & 20640 \\
\hline
\end{tabular}




\begin{tabular}{|c|c|c|c|c|c|c|c|c|}
\hline 1905 & 50777 & 19547 & 6083 & 78400 & 8778 & 9882 & 1515 & 21869 \\
\hline 1906 & 65806 & 21244 & 6757 & 95962 & 9574 & 10723 & 1384 & 23379 \\
\hline 1907 & 91065 & 22659 & 4924 & 121002 & 11098 & 11198 & 1124 & 25409 \\
\hline 1908 & 78301 & 23300 & 5602 & 109785 & 11353 & 11097 & 1165 & 25328 \\
\hline 1909 & 77481 & 22971 & 5681 & 108866 & 12293 & 10948 & 1154 & 26442 \\
\hline 1910 & 83312 & 23735 & 6164 & 116221 & 12252 & 10409 & 1022 & 25679 \\
\hline 1911 & 93998 & 23861 & 7591 & 128726 & 13112 & 10979 & 1095 & 27367 \\
\hline 1912 & 101630 & 25636 & 9506 & 140704 & 13719 & 11429 & 1196 & 28967 \\
\hline 1913 & 111686 & 27315 & 11524 & 154931 & 15256 & 12478 & 1803 & 32701 \\
\hline 1914 & 107767 & 26242 & 12225 & 150567 & 16681 & 12922 & 1832 & 34276 \\
\hline 1915 & 115639 & 26778 & 34517 & 164251 & 34517 & 16051 & 2032 & 116747 \\
\hline 1916 & 116432 & 29375 & 23236 & 178853 & 23964 & 19114 & 2087 & 301172 \\
\hline 1917 & 105368 & 27738 & 32904 & 173442 & 33810 & 17868 & 1793 & 449645 \\
\hline 1918 & 140453 & 35354 & 60852 & 246433 & 84583 & 11203 & 1832 & 545490 \\
\hline 1919 & 114256 & 45262 & 61472 & 229427 & 33025 & 11345 & 2823 & 61660 \\
\hline 1920 & 211214 & 59649 & 62447 & 344021 & 21540 & 14488 & 3186 & 44995 \\
\hline 1921 & 128373 & 57233 & 38167 & 233698 & 21679 & 14858 & 4161 & 47700 \\
\hline 1922 & 181141 & 51922 & 55643 & 302639 & 18694 & 13776 & 3764 & 42506 \\
\hline 1923 & 174859 & 51370 & 59424 & 303041 & 18546 & 14808 & 3795 & 43510 \\
\hline 1924 & 176284 & 47325 & 62486 & 303092 & 19340 & 15661 & 3939 & 46360 \\
\hline 1925 & 179973 & 48430 & 62656 & 309336 & 21353 & 16876 & 5024 & 51047 \\
\hline 1926 & 183838 & 48118 & 69838 & 321230 & 27529 & 19641 & 4704 & 60795 \\
\hline 1927 & 189267 & 49939 & 64819 & 322834 & 28033 & 21390 & 5343 & 63105 \\
\hline 1928 & 204214 & 54388 & 64612 & 345147 & 27350 & 21871 & 4789 & 62632 \\
\hline 1929 & 207740 & 60332 & 65787 & 361251 & 27779 & 22109 & 4736 & 63649 \\
\hline 1930 & 145351 & 52786 & 52295 & 278382 & 23261 & 20143 & 4634 & 57276 \\
\hline 1931 & 98479 & 39832 & 32393 & 189220 & 17773 & 17197 & 3624 & 45629 \\
\hline 1932 & 79728 & 36327 & 20441 & 151436 & 15383 & 17725 & 2878 & 42432 \\
\hline 1933 & 70067 & 40584 & 18308 & 142571 & 16017 & 19009 & 2792 & 44244 \\
\hline 1934 & 70183 & 42854 & 27699 & 154092 & 14266 & 18426 & 2672 & 41498 \\
\hline 1935 & 69397 & 45845 & 30286 & 160146 & 13099 & 17315 & 3217 & 40056 \\
\hline 1936 & 68860 & 52165 & 34142 & 176772 & 13364 & 19190 & 3505 & 43008 \\
\hline 1937 & 77420 & 56180 & 35477 & 197136 & 14254 & 20810 & 3245 & 45600 \\
\hline 1938 & 84697 & 56481 & 38995 & 209667 & 14945 & 22913 & 3664 & 50162 \\
\hline 1939 & 48827 & 40882 & 28446 & 133349 & 11597 & 21634 & 3684 & 44771 \\
\hline
\end{tabular}

In addition, parcels to and from the New Zealand Expeditionary Force (NZEF), which served overseas during World War One, were counted separately. 
New Zealand Expeditionary Force (NZEF) Parcels 1915-1919

\begin{tabular}{|c|c|c|}
\hline Year & $\begin{array}{l}\text { Received in NZ } \\
\text { from NZEF }\end{array}$ & $\begin{array}{l}\text { Despatched from } \\
\text { NZ to NZEF }\end{array}$ \\
\hline 1915 & 2128 & 60214 \\
\hline 1916 & 2516 & 251164 \\
\hline 1917 & 891 & 392235 \\
\hline 1918 & 1415 & 442318 \\
\hline 1919 & 384 & 9851 \\
\hline
\end{tabular}

Source: New Zealand Official Yearbooks

While trade between New Zealand and Australia was dropping rapidly after 1860, using this "parcel exchange" gauge, we might argue that New Zealand and Australian bonds were still strong from 1893 to 1914. Belich argues that the "Tasman world in 1912-13 was weaker than in 1890"; Arnold argues that New Zealanders resented the role of "Australian intervention" in the 1913 strike. ${ }^{23}$ In this paper, I disagree with the characterization that the two communities, especially the union community were "moving apart"; rather, I argue, there was a strong push for trans-Tasman union and socialist federation up to 1913. Any "resentment" of Australian interference is only true from a militant socialist perspective.

\section{Trans-Tasman "Crisscrossing" Biography}

Australian but mostly New Zealand-born demographers - Mick Borrie, Arnold, Gordon Carmichael and Ian Pool - have revealed aggregate patterns in Tasman population movements and, in the process, they have emphasized a "Tasman world" before 1914 and after the 1970s. Despite this, there are a range of views in the historiography about trans-Tasman relations. Some, like Marilyn Lake in her recent 2014 "Presidential Address" to the Australian Historical Association Conference, emphasize that New Zealand and Australia were two countries with two histories. ${ }^{24}$ Others, like Philippa Mein Smith posit "one history but two historiographies" and have worked on comparative relational and regional history. ${ }^{25}$ Others emphasize regular episodic and unweighted waves of closer relations. ${ }^{26}$ Despite this, there is little qualitative work on those who actually crossed the Tasman; Rosemary Baird's recent $\mathrm{PhD}$ thesis is one of the few exceptions, but it concentrates on the later period from 1965 to $1995 .^{27}$

Certainly there is nothing about "Tasman Crossings" to match Daniel T. Rodgers' 1998 Atlantic Crossings on how progressive ideas flowed around the world before the USA became isolationist after World War Two. ${ }^{28}$ There are snippets about policy exchange, especially industrial arbitration for the early period and market reforms, superannuation and accident compensation for the later period. ${ }^{29}$ Tasman crossings differed from Atlantic crossings, of course. The former involved a much smaller part of the world and a more compact process that is more embodied than Rodgers' study. How do you measure the influence and effect of trans-Tasman exchange when the borders were so close and free? The exchange, moreover, was often scarcely visible, not always identified, signified, or at least differentiated physically or even by accents.

In an interesting departure, however, Michael Sharkey considered this issue in his 2012 biography of David McKee Wright - one of three New Zealand editors of the iconic Bulletin in the twentieth century. Sharkey laments the paucity of trans-Tasman socio-cultural accounts. There were three Australian-born editors of the Maoriland Worker in its first ten years, which begs 
analysis. ${ }^{30}$ He hoped that his biography of Wright would "point to other bridges in New Zealand and Australian cultural history" and called for a raft of collective biographies, including the wave of New Zealand writers in Australia including Jean Devanny and Ruth Park. ${ }^{31}$

It is clear that some, but by no means all, Australians and New Zealanders crisscrossing the Tasman bore cultural baggage that was socially and politically significant. In biographical terms, a number of historians such as O'Farrell and Miles Fairburn have considered the early twentieth-century example of Victorian-born Howard Elliott, the sectarian Baptist Minister (18771956) who left Queensland for Auckland in 1909 and founded the Protestant Political Association in 1917. He accused Catholics of disloyalty and protested against their attempts to have seminarians and Christian and Marist brothers exempt from conscription. From an alleged total of 200,000 members in 1919, support for the PPA declined rapidly as wartime tensions eased. O'Farrell suggested Elliott misread New Zealand politics in the light of his Australian experience, greatly exaggerating the influence of Catholicism on the NZLP, since nothing similar to the Catholic role in the ALP was ever to exist in New Zealand. ${ }^{32}$ If the challenge of the right was strong during World War One in New Zealand, so too was the challenge from the Left especially before WW1. Conflict reached a violent crescendo in the Great Strike in 1913.

The historians writing the biographies of Hughes and Holland also had trans-Tasman histories. Senior Australian academic Laurie Fitzhardinge and his New Zealand doctoral student, O'Farrell, were working on their biographies at the same time in the same corridor of the Research School of Social Sciences at the Australian National University and they were both published in 1964. Australian Freddy Wood, who, along with Manning Clark, examined O'Farrell's thesis, was supervising Bruce Brown's MA on the NZLP at the same time. Neither the biographies on Hughes nor Holland discussed the 1913 General Strike in trans-Tasman terms. In reviews of their books it was usually noted that Fitzhardinge seemed to empathize with Hughes more than O'Farrell did with Holland. ${ }^{33}$ Ian Turner sent O'Farrell long and short versions of his review of the Holland biography privately. O'Farrell replied acknowledging his lack of identification with Holland, noting that "no-one understands anyone else, and damn few understand themselves." He agreed that the conflict for social democrats was to reconcile the ultimate goal of social reconstruction with the immediate goal of votes and that the conflict was expressed in two ways: "in the struggle of factions within social democratic movements, and in the tearing contradictions within the hearts and minds of individual social democrats." 34 Above all O'Farrell thanked Turner for his views "Australian willing or not" for he was "very pleased to find someone who saw that I was attempting to use Holland to dramatize and personalize the socialist dilemma." 35

Hughes and Holland's relationship is a good way to tease out effective relations between Australia and New Zealand, personalizing and dramatizing the relationships between their respective labour movements. It was a "close-run matter" that the Sydney wharfies did not come out in support of New Zealand striking workers in late 1913. I argue that 1913-1914 represents a turning point of sorts, when even dreams of trans-Tasman fraternalism died. Hughes and Holland personify this connection and contingency.

\section{Trans-Tasman Fraternalism, Billy Hughes and Harry Holland}

Trans-Tasman fraternalism flourished after the defeat of the 1890 Maritime Strike. ${ }^{36}$ There is no question that the 1890 strike and its defeat pricked the contemporary utopian bubble. About 13 percent of the workforce struck in the ten week strike in 1890 involving union recognition. The affiliates of the Australian Maritime Council came out in support of getting union recognition for 
its affiliates. Ten days later the New Zealand Maritime Council acceded to the request of the Australasia Council that its members not work Union Steam Ship company vessels.

Surprisingly, however, the New Zealand-Australian union solidarity was relatively unaffected by the 1890 Maritime Strike. One could argue further, as indeed John Salmond and Peter Franks have done, that the federation of Australia in 1901 made little difference to transTasman union fraternalism. ${ }^{37}$ The Seamen's Union formalized trans-Tasman federation after $1890 .^{38}$ Large sums of money were sent across the Tasman including to the Auckland Bootmakers in 1891. ${ }^{39}$ John Lomas travelled to Australia drumming up support for New Zealand's West Coast miners in Victoria in $1891 .{ }^{40}$ The Amalgamated Shearers Union helped revive unionism among New Zealand shearers between 1891 and 1893; James McDonald made three organizing trips. ${ }^{41}$ The traffic in union leaders across the Tasman Sea was significant but it was greatest between 1901 and 1914.

Strenuous efforts were being made, moreover, to formalize the relationships. The labour movements in the seven colonies of Australasia held eight intercolonial conferences from 1879 to 1898 and then there were seven interstate Australian congresses, 1902 to $1927 .{ }^{42}$ The first intercolonial congress in the wake of 1890, in Ballarat in 1891, raised the issue of an Australasian Federation of Labor because "the labour organizations of Australasia were practically unanimous in holding certain opinions and social politics." As the evidence to the Royal Commission on Strikes noted:

the last great struggle has taught us that under our present system a single Union or national group of Unions might at any time involve every Union in Australasia in what the majority might consider an unsought and impossible conflict ... The Australian Labour Federation (Queensland) convened an Intercolonial Conference of delegates, for the purpose of preparing a basis of federation, with a view to formally instituting at the 7th Trades and Labour Conference, to be held at Ballarat in April next year, an Australasian Federation of Labour. ${ }^{43}$

The Australian councils held post-Federation interstate congresses in 1902 and 1907, which New Zealand representatives attended. In 1906, the Wellington Trades and Labour Council called upon New Zealand Trades and Labour Council's executive to "open up a correspondence with the Australian Councils, with a view to arranging for intercolonial Trades and Labour Councils' conferences in the near future." Only two of the sixteen TLC representatives voted against Hampton's motion for "intercourse." 44 Tom Beaston attended the 1907 "interstate" congress in Melbourne, the first time a representative of New Zealand unions had attended a Commonwealth congress; indeed, he was elected Vice-Chairman. ${ }^{45}$ So, New Zealand representation grew after $1901^{46}$

New Zealand seemed to commentators to be a relatively prosperous country without strikes at this time. For Henry Demarest Lloyd it was the "least bad country" that had discovered the "anti-toxin of revolution." 47 New Zealand was not expected to breed ideas and movements such as syndicalism, still less to see the practical results of general or wave-like strike action. The state had implemented the Industrial Conciliation and Arbitration Act and was intent on making strikes illegal with its 1905 and 1908 amendments. ${ }^{48}$ The Blackball "Tuckertime" strike (when the miners struck for half hour lunch breaks), however, broke the strike drought. ${ }^{49}$ The number of strikes rose from 1 in 1909 to a crescendo of 73 in 1913.

The Blackball "strikers" formed the Federation of Miners in $1908,{ }^{50}$ which became the FOL in 1909. ${ }^{51}$ Their goal is usually held to have been to unite workers into one big union, and 
that included trans-Tasman federation, and destroy capitalism by means of a general strike. The miners, the seamen, the shearers and the wharfies began with their own trans-Tasman federations. In 1908 the New Zealand Waterside Workers Federation in Wellington decided to "send" Dave McLaren "over to Australia to try and bring about an alliance with the Waterside Workers there." ${ }^{52}$ After several conferences were held on the subject, a constitution was draw up. William Thomas Young, a rising figure in the New Zealand Federated Seamen's Union, attended the Melbourne Conference in 1909 and wholeheartedly supported trans-Tasman amalgamation. From the time of that conference in 1909:

New Zealand has been moving in the direction of linking up with Australia with the object of having the one organization of seamen on this side of the Line, operating under one uniform set of rules and conditions of work. Some time ago a plebiscite vote of New Zealand members was taken on the general question of amalgamation with Australia. The proposal was adopted by an overwhelming majority. In fact there were very few votes against the proposal. ${ }^{53}$

While in Australia, McLaren had critical meetings with Andrew Fisher and other government ministers including William Morris Hughes, then Attorney-General.

At the same time, Hughes was attempting to form an Australasian federation of transport workers. ${ }^{54}$ After the Sydney branch strike in 1908 Hughes founded and became the inaugural president of the Transport Workers Council, which consisted of unions affected by the strike. He intended to form a larger organization which would include members of the officers' guild, engineers, seamen, and carters and drivers - veritable vertical integration - and he expected that body to extend to states beyond New South Wales and to New Zealand, as he suggested:

the next thing to do was to try and form a Council of the whole of the Transport Workers of Australasia consisting of the Officers Guild, Engineers, Seamen, Carters and Drivers who cart to and from the wharves and wharf labourers and Stevedores and having made a start in New South Wales he did not think it would be long before it could be extended to the Whole of the States and also New Zealand. ${ }^{55}$

Miners' emissaries crisscrossed the Tasman. Robert Semple's aim had been to fuse Australian coalminers and seamen with the Red Feds, to minimize the danger of scabbing and progress industrial unionism, by forming One Big Union across the Tasman. The FOL executive drafted an agreement to this end and Semple crossed the Tasman in 1912 to secure the agreement of watersiders, as well as coalminers, in Victoria and New South Wales. ${ }^{56}$ Pat Hickey and Paddy Webb also crossed the Tasman in search of aid for the strikes and solicited substantial contributions, principally from miners, based on their trans-Tasman experience and connections. ${ }^{57}$ Paddy Webb's brother-in-law, Alf Plant, was a member of Wonthaggi unions' committee of management and there were strong links between New Zealand and coalmining towns in Victoria. After much agitation, the "The Australasian Coal Miners' Association" was formed in 1913. ${ }^{58}$

Holland, too, looked to New Zealand's involvement in a broader movement. He became the general secretary of the Socialist Federation of Australasia (SFA) in 1907 and edited the militant socialist publication the International Socialist Review for Australasia from 1907 to 1910. Close personal links between the New Zealand and Australian socialist parties were forged in 1908 at its first conference when the New Zealand party affiliated with the Australian federation in the cause of "revolutionary activism" and "One Big Union." This facilitated the sojourns of Australians in New Zealand, including those of Bob Ross, Peter Bowling and Harry Scott Bennett. When Holland told John P. (Jack) Desmond, vice president of the Greymouth Wharf Labourers, 
who was visiting Holland in Sydney in December 1911, that the Rotorua hot springs was just the remedy he needed for his crook knee, Desmond launched an appeal in March 1912 in the Maoriland Worker to "Get Him New Zealand." 59 Socialists like Harry Atkinson and Mrs Janet McTaggart of Runanga all contributed their shillings to the cause. Holland arrived in New Zealand just in time for the Waihi Strike which traumatized the town of Waihi in 1912 when the police were sent in, four leaders were sentenced to imprisonment, sixty miners were arrested and one was killed. New Zealand unionists raised $£ 6500$ towards the strike while, encouraged by Hickey's and Webb's trans-Tasman visits, Australian unionists contributed $£ 9000 .{ }^{60}$ Holland and Ross wrote the history of the Waihi Strike. ${ }^{61}$

Other scholars have considered international networks: Shelton Stromquist has considered municipal socialists; Rob Weir, the Knights of Labour; and Erik Olssen, inter alia, the British Ben Tillett and Tom Mann and Canadians H. M. Fitzgerald and J. B. King. But here was a difference in degree and kind in the interactions across the Tasman compared with elsewhere. The exchange of people and ideas was particularly potent, as the parcel exchange discussed above shows until at least 1913-14.

\section{The Role of Billy Hughes in the Containment of Trans-Tasman Fraternalism, 1913-1914}

Not only people and common cause, but also disagreements and rivalries crossed the Tasman, including those between Holland and Hughes. Their activism and disputes spanned the Tasman Sea; their respective biographies each chart part of the narrative but not the denouement. ${ }^{62}$ In some ways Holland and Hughes were similar. They were contemporaries who both joined the Australian Socialist Party (ASP) in 1892. Both had qualms about immigration lowering standards of living and raising competition for jobs. Both had turned to organizing unions to cultivate power bases; unions would assist a workers' party to power. Both supported political parties in principle. Hughes organized the Sydney wharf labourers in 1899 largely because, as a member of the NSW parliament, he was beyond the intimidation of the employers and so was a match for them. Hughes also organized and became president of the Trolley, Draymen and Carters' Union and the Waterside Workers' Federation. For his part, Holland was President of the Tailoresses in 19011902 and organized the Newcastle Wharf labourers, separate from that in Sydney.

But Holland's and Hughes's outlooks diverged from an early stage. Holland was one of a group of "incorruptibles" in the Socialist League. He had been a Salvation Army member but redirected his energies towards socialism. In 1898 Holland had left the ALP, which he deemed to be insufficiently socialist. Indeed, his unbending nature saw him jailed in both Australia and New Zealand (for libel in 1896 and for sedition in Broken Hill in 1909 and in New Zealand in 1914), based on his provocative public speeches. Hughes' background was as much in the shorter hours movement as it was in any particular union. Above all, Hughes did not want the ALP to be militantly socialist. He was a member of the NSW Legislative Assembly from 1894 to 1901 and federal Labor MP from 1901 until (seems like forever but it was only) 1952 and was happy to be part of a party that espoused a form of labourism very little different from Deakinite or Seddonite Liberalism.

Holland and Hughes clashed continually. Their first falling out was over the gradualism of the parliamentarians and the socialization objective in 1896 and 1898. They fell out spectacularly over support for the tailoresses strike in $1901 .{ }^{63}$ Holland was on record describing Hughes as a "blackleg," a "scab" and a "rat." He was sent into a conference with Hughes when he asked the watersiders for assistance with the tailoresses' dispute in 1901 but, even after the leaders civilly conferred, the watersiders did not support the tailoresses. Hughes and Holland took different 
positions over the Newcastle wharf labourers' union in 1902, the coal-lumpers' strike, 1907-1908 and the Broken Hill strike in 1909. Indeed, Holland accused Hughes of being responsible for his arrest over the latter dispute. Indirectly they also clashed over the 1909 Northern Miners' Federation strike and the tensions spilled over into the political arena. For "sheer spoiling," as Fitzhardinge argues, Holland stood against Hughes in 1910 in the West Sydney seat, knowing that he would not win but publicly contesting issues with Hughes. ${ }^{64}$ As Holland wrote "So long as I can get on the nomination paper I'll make things hum for Hughes." 65

Their paths had diverged considerably, too. By 1902 Hughes had qualified in law, had been in the NSW parliament from 1895 to 1901 and then the Commonwealth parliament. He was a senior member of the Federal Opposition, having already been Attorney-General twice in Fisher's Labor Governments' 1908 to 1909 and 1910 to 1913. The gulf between him and Holland in terms of position and influence only widened. They clashed most spectacularly over strikes. Both viewed strikes as a "means to an end" but they differed over the social point of the strikes. Industrial unionists used strikes to settle disputes and to wage direct action or "industrial warfare." As Hickey urged, even if you had signed an arbitration agreement, the "moment an opportunity occurs to better your conditions, break your agreement." 66 Hughes, and those he represented, struck in order to force reluctant employers into binding legal arbitration. Hughes supported the unions he represented striking for a month in 1908 in order to force coastal ship owners into arbitration. Hughes chaired a congress of coal strikes in 1910 and tried to achieve the same in Newcastle eighteen months later.

To some extent, the trauma of 1890 bore down on Hughes and Holland differently. Hughes had been a radical Balmain bookshop owner, a single-tax reformer, who was deeply scarred from the 1890 experience: he had derived a "deep distrust of the general strikes and the belief in legislative reform and arbitration which were the keynotes of his later industrial policy."67 Hughes, it was reported in the New Zealand press, called on those to consider the repercussions of a general strike: "Within twenty-four hours or less" there would be no "food, no milk, no meat, no bread, no fodder for stable-fed horses" and no electricity. Order might not be maintained and, if riots occurred, it would be a nightmare and "social suicide." 68 Holland was against neither arbitration nor political parties but was perennially optimistic about the greater effectiveness of strikes.

In early November 1913 it appeared as if the New Zealand strike was spreading internationally. ${ }^{69}$ Newspaper accounts declared that the "trouble is likely to extend beyond New Zealand; it is affecting Australia, and even Great Britain. The wharf laborers of Sydney have placed an embargo on New Zealand cargo, and in London" and the "waterside workers are likely to refuse to have anything to do with 'scab' ships." 70 A transport strike in Australia was still feared in December 1913. ${ }^{71}$ However, Hughes did everything he could to stop the New Zealand strike spreading to Australia, and he was successful.

Hughes called a conference for 1 December in Sydney at the headquarters of the Seamen's Union to discuss the position on the waterfront. It was one of the most representative unionist gatherings in Australia up to that date, with delegates on behalf of 200,000 workers. Bill Parry attended as an envoy of the New Zealand Federation of Labour. By taking the chair, Hughes was assured control of the conference, which commenced at eleven in the morning and ended at six in the evening, with its proceedings "conducted in the greatest secrecy." 72 Hughes managed to have a "steadying influence" and his view prevailed. ${ }^{73}$ After an additional specific seamen's conference on 4 December, the "Australians" did not "go out in sympathy" but called on the dispute to be submitted to arbitration. Using a similar tactic to that he deployed in the 1909 miners' strike,

Journal of New Zealand Studies NS18 (2014), 118-136 
Hughes succeeded in gaining a resolution that Australian cargo would be handled but cargo from New Zealand could only be loaded or unloaded with authority from the Committee of Management; which, in effect, meant he would forbid direct action by Australian wharf labourers in support of the strike. Thereafter, Australian wharf labourers and seamen limited their support for the strike to donations, probably contributing about a third of the total funds raised. ${ }^{74}$ The Australian unions called off their official embargo on New Zealand trade and commerce at the Combined Unions conference in Sydney just before Christmas calling for a "further special appeal to the Australian unionists for relief of distress in New Zealand occasioned by the strike." 75 Among the letters read out at the Sydney ASP meeting in January 2014 was one from Hickey thanking the party for its donation of $£ 715 \mathrm{~s}$ raised at a demonstration in the Domain. ${ }^{76}$

Hughes opposed the strike crossing the Tasman because he had Australian arbitration objectives ${ }^{77}$ Hughes' greatest achievement as a trade union leader was the 1914 Commonwealth Award for waterside workers. It set uniform wage standards for wharf labourers across Australia and was the first Commonwealth award for casual workers, so it became the benchmark for other unskilled and casual workers. ${ }^{78}$ Industrial peace on the Australian waterfront was a crucial prerequisite for the award. New Zealand newspapers noted the "extraordinary spectacle" of an onlooker "1300 miles away, dictating terms of surrender." Hughes' position was "The Federation contained thousands of the best workmen in the colonies, and we cannot consent to their destruction." 79 Why, Hughes asked "should unionists go out and be slaughtered"? He believed in preventing the mine-owners from defeating the men in Newcastle in 1909 and he wanted to do the same in New Zealand in 1913. Industrial unionists were "gasconading" about what a general strike could achieve. ${ }^{80}$

The militants knew what Hughes' position would be, as letters between Josiah Cocking and Harry Holland reveal. Cocking (1867-1960) was Holland's best friend. They were both "Salvationist Socialists," as described in a biography of Cocking written by his son. ${ }^{81}$ Cocking was a miner and a verse writer who published under pseudonyms such as "Dandelion" and "Capsicum." He also kept diaries. ${ }^{82}$ While there were entries before 1904 and after 1919, in between the diaries are more in the nature of a common book with his poems, lists of books he had read, photos, letters to the editor and inward correspondence. ${ }^{83}$ The letters between Annie and Harry Holland to Cocking, indicate their closeness. Annie had updated Cocking: "One of the last things Harry said to me when he went away [to prison] was to be sure \& send you the papers with his trial. I sent you his speech; but in case you didn't get it I will send you another over \& I will also send you the book on the Waihi Strike." On his release, Holland wrote that "Your letter apart from one or 2 brief notes, was the only communication I was allowed to receive in addition to wife's letters." $\mathrm{He}$ could not tell Cocking how pleased he was that "they let me have it." It made him remember the other letters over the years Cocking had written to him: Cocking was the first to write to him when "I went into Darlinghurst jail 18 years ago." When he was jailed over the Broken Hill strike "you were again among those who wrote cheering words." He so appreciated Cocking's letter to him "while at Wellington jail as a result of the greatest industrial upheaval Australasia has yet seen." Holland saw his New Zealand activities are part of regional politics and, at that time, fully expected to return to Australia.

Cocking had been Holland's mainstay contributor to the International Socialist Review from 1907 to 1912, contributing one-to-two articles each week to it as well as verse. Their private correspondence also indicates "their" views on Hughes. In 1909 Cocking wrote that in several respects the 1909 strike "surpassed earlier strikes" because the three mining districts - Newcastle (including Maitland), the South and the West - were all out together and were led "by a class- 
conscious, uncompromising, fearless Socialist, and gives promise of spreading like a bush fire at Christmas time." Both Cocking and Holland wanted it to spread and saw Hughes as their major obstacle. Cocking warned that the strike was being propagated according to the scientific principles of the New Unionists ... until Hughes appeared upon the scene. Hughes seems to be the wet blanket that for a time has damped the fire of militant fellow-feeling kindled by Bowing \& the other Socialists \& New Unionist in the interests of the seamen and other water siders. Never before in the history of Australia have so many thousands of wealth-creators acted upon the principles that "an injury to one worker is an injury to all." 85

Similarly in 1911 Holland wrote to Cocking about his newspaper duel with Hughes:

Last Saturday week Hughes, in "The Case for Labor" made a veiled attack on the strikes. On the following Tuesday the Daily Telegraph published a very lengthy criticism from me of Hughes' attitude. Last Saturday he devoted 2 columns of the "Case" in reply to my letter; and to-day the "DT" again publishes my reply — a good long column of it. Don't worry-friendly criticisms never hurt me. ${ }^{86}$

Cocking was right to see Hughes as the greatest threat to the "growth of the Socialistic seed sown ... by Holland, Bowling, Batno, Moroney, Thompson, Mann, Tillett, May Hickson, \& others." 87 Hughes was on record as being implacably opposed to the "Biggars, Bowling, Burns, Brennan, Holland \& others" who were industrial unionists. ${ }^{88}$

Hughes was identified in the media, too, playing a crucial intercolonial role, regarded as the critical figure preventing the strike crossing the Tasman. ${ }^{89}$ Cables and correspondence crisscrossed the Tasman to and from him. ${ }^{90}$ Hughes called for a "reasonable spirit" and the dispute to go to arbitration, in 'cabled communications to the Employers', Farmers' and Citizens' Defence Committee." "91 To the latter he cabled "we desire industrial peace. We believe in the settlement of industrial disputes by arbitration" and called on employers to go to arbitration and to embrace "sweet reasonableness." "92 This "cablegram" correspondence could not have been more public, being publicized in all the New Zealand newspapers as well as the Sydney Morning Herald.${ }^{93}$ Most New Zealanders came to this view too; when McLaren and McKenzie wrote a manifesto against the "strike craze" and the "absolutely mad-brained appeal for the general strike," rather than "resenting interference" they took solace that "the leading Labour men of Australia" Hughes and Holman condemned it too. ${ }^{94}$

\section{Conclusion: Trans-Tasman Labour Relations}

Along with the 1890 Maritime Strike and the 1951 Waterfront Lockout, 1913 stands out as one of the three major industrial confrontations in New Zealand's history. The 1913 strike lasted eight weeks (two days more than the 1890 strike) and involved nearly a fifth of unionists. Keith Sinclair captures the level of animosity when he argued that the years 1912 and 1913 "witnessed the most violent scenes since the Anglo-Maori wars as the Government, the employers and the cow cockies smashed the Red Feds. New Zealand came closer to class war then than at any other time in its history." 95 The struggle in 1913 was not just a fight over wages and conditions, of course, it was a power struggle. It was not just a power struggle between the workers and employers, however, but between groups of workers who wished to lead the antipodean movement, which was in 1913 intercolonial.

Militants, like Holland and Cocking, hoped that the 1913 strike might cross the Tasman. 
It did not, unlike 1890 Maritime Strike. Crossing the Tasman was never an issue in 1951. The dream or the illusion of trans-Tasman union federation that had begun in the 1880s ended in 1913. What if the strike had crossed the Tasman? Clearly the strikers would never have "won." But the containment of militancy would have been stronger. As it was, unions and labour came out of 1913 in a much stronger position than after the 1890 strike. Holland might have returned to Australia. As it was, 1913 together with the war signals the end of a phase of trans-Tasman federation and progressive utopianism. Hardly anyone dreamt of trans-Tasman strikes after then. By 1913 and 1914 even the militant socialists who had sought trans-Tasman federation were resigned to national vistas. $^{96}$ They now believed that they had to unite internally by labour party and peak union organization to position themselves to take power, some, like Holland, believing that capitalism would collapse.

Holland was the NZLP representative at the 1921 Australasian Trade Union Congress called by the ALP. ${ }^{97}$ The Congress officially adopted the socialization objective by means of a "framework of an elaborate one-big-union organization embodying the principle of industrial as against craft unionism." "socialization of industrial campaign." It did very little. The growing absorption in national problems and national unity after 1913 was at the expense of international socialist objectives. ${ }^{99}$ While a number of unions remained Australasian for most of the twentieth century fraternity was occupational or nominal. ${ }^{100}$ The most spectacularly optimistic was the Australasian Council of Trade Unions formed in 1927 and based on the "hope that eventually the New Zealand Alliance of Labor would federate with the Australian body." A more realistic federation, the Australian Council of Trade Unions, emerged seamlessly in 1947. Finally, as is so well-known, a legacy of this phase of trans-Tasman fraternity was that there were five Australian-born in the New Zealand labour cabinet in 1935 and, even if we discount Alfred Hindmarsh since he was an Australian who crossed the Tasman in 1878, from 1919 to 1939 the NZLP was led by Australian-born socialists. While it is easiest to discuss the key players and leaders, the trans-Tasman story of 1913 involves the "Jack Desmonds" and "Joe Cockings" who did not migrate but whose correspondence and trips across "the ditch" reveal the wide dissemination of knowledge and understanding about labour relations in the region which reached its peak in 1913.

\footnotetext{
${ }^{1}$ International Socialist Review, April 2 1910, Josiah Cocking, notebook diary, E (December 41909 - May 17 1920), Cultural Collections, University of Newcastle (UON).

${ }^{2}$ Erik Olssen, The Red Feds: Revolutionary Industrial Unionism and the New Zealand Federation of Labour 1908-1913 (Auckland: Auckland University Press, 1988).

${ }^{3}$ Melanie Nolan (ed.), Revolution: The 1913 Great Strike in New Zealand (Christchurch: Canterbury University Press, 2005). The strikes in New Zealand became known as the "Great Strike" in Wellington and the "General Strike" in Auckland.

4 "1913 Strike - War on the Wharves," 22 August to 25 November 2006. Jared Davidson, "'Sites of Struggle' Self-guided booklet," Wellington History Walk (Wellington: Museum of Wellington City and Sea, 2013). See also Peter Clayworth, "Wellington's Sites of Struggle - 1913 Strike Centenary Walks," in Labour History Project Bulletin, no. 59 (December 2013): 6-8.
} 
${ }^{5}$ Cybele Locke, “'Tatau Tatau' vs 'Half-Caste Maori' Scabs” (The People's History Series 2013, hosted by the Museum of Wellington City \& Sea and the National Library of New Zealand, National Library of New Zealand, Wellington, 15 October 2013).

${ }^{6}$ Dominion Post, “A Century since the Cossacks. Horses Mounted for 1913 Strike Recreation,” 5 November 2013.

${ }^{7}$ See James Belich, "1913," in Paradise Reforged: A History of the New Zealanders: From the 1880s to the Year 2000 (Auckland: Penguin Press, 2001), Chapter 3, "Trouble in Paradise," 87-95.

${ }^{8}$ An earlier version of this paper was one of six seminars, Melanie Nolan, "1913: Still Relevant After All These Years?" (The People's History Series 2013).

${ }^{9}$ Patrick O'Farrell, "Holland, Henry Edmund (1868-1993)," and L. H. Fitzhardinge, "Hughes, William Morris (1862-1952)," in Australian Dictionary of Biography vol. 9, 1891-1939 Gil-Las, eds. Bede Nairn and Geoffrey Serle (Melbourne: Melbourne University Press, 1983), 336-7, 393-400. Patrick O'Farrell, "Holland, Henry Edmund 1868-1933," in The Dictionary of New Zealand Biography, vol. 3, 1900-1920 (Wellington: Bridget Williams Books/Department of Internal Affairs, 1996), 226-9.

${ }^{10}$ P. J. O'Farrell, "Formation of the New Zealand Labour Party," Historical Studies 10, no. 38 (May 1962): 197.

${ }^{11}$ W. B. Sutch, Poverty and Progress in New Zealand (Wellington: Reed, 1941), and The Quest for Security in New Zealand (Harmondsworth: Penguin Books, 1942), and The Quest for Security in New Zealand 1840 1966 (Auckland: Oxford University Press, 1966); H. O. Roth, Trade Unions in New Zealand: Past and Present (Wellington: Reed, 1973).

${ }^{12}$ W. H. Oliver, "Reeves, Sinclair and the Social Pattern," in The Feel of Truth: Essays in New Zealand and Pacific History Presented to F. L. W. Wood and J. C. Beaglehole on the Occasion of their Retirement, ed. Peter Munz (Wellington: Reed, 1969), 163-90.

${ }^{13}$ D. J. Murphy, "The Tramway and General Strike, 1912," in The Big Strikes: Queensland 1889-1965 (Brisbane: University of Queensland Press, 1983); Claire Fitzpatrick, "Dublin General Strike, 1913," in The International Encyclopedia of Revolution and Protest, 1500 to the Present, ed. Immanuel Ness (New York: Blackwell Publishing, 2009). For contemporary discussion of the Brisbane strike in New Zealand, see Post, 7 November 1913.

${ }^{14}$ Edward Shorter and Charles Tilly, Strikes in France: 1830-1968 (London: Cambridge University Press, 1974). Leopold H. Haimson and Charles Tilly (eds.), Strikes, Wars, and Revolutions in an International Perspective: Strike Waves in the Late Nineteenth and Early Twentieth Centuries (Cambridge: Cambridge University Press, 1989).

${ }^{15}$ Olssen, for instance, restricts discussion to a few pages, The Red Feds, 200-03.

${ }^{16}$ W. D. Borrie, The European Peopling of Australasia: A Demographic History 1788-1988 (Canberra: Demography Program, Research School of Social Sciences, Australian National University, 1994), 293-98.

${ }^{17}$ For instance, Robert Semple (1873-1955) was black-listed for his role in the 1903-04 Victorian Coal Strike and moved to New Zealand (Len Richardson, "Robert Semple 1873-1955," Dictionary of New Zealand Biography). See also Barry Gustafson, From the Cradle to the Grave: A Biography of Michael Joseph Savage (Auckland: Reed Methuen, 1986). Some historians have emphasized that radicalism was imported. See P. J. O'Farrell “The Workers in Grey District Politics, 1865-1913: A Study of New Zealand Journal of New Zealand Studies NS18 (2014), 118-136 
Liberalism and Socialism" (MA thesis, University of New Zealand, Canterbury, 1955). Most argue instead that there were local disputes and origins. Len Richardson, Coal, Class and Community: The United Mineworkers of New Zealand, 1880-1960 (Auckland: Auckland University Press, 1995).

${ }^{18}$ Rollo Arnold, "Some Australasian Aspects of New Zealand Life, 1890-1913," New Zealand Journal of History 4, no. 1 (April 1970): 54-76; and "The Australasian Peoples, 1888-1915," in Tasman Relations: New Zealand and Australia, 1788-1988, ed. Keith Sinclair (Auckland: Auckland University Press, 1987), 52-70.

${ }^{19}$ See Graph 5 "Direction of Exports 1861 to 1976" and Graph 6 "Direction of Imports 1861-1976" in The Oxford History of New Zealand (Auckland: Oxford University Press, 1981), 474-75.

${ }^{20}$ Belich, Paradise Reforged.

${ }^{21}$ Arnold, "Some Australasian Aspects of New Zealand Life, 1890-1913."

${ }^{22}$ See Patrick O'Farrell, Letters from Irish Australia 1825-1929 (Sydney: NSW University Press and Ulster Historical Foundation, 1984); Charlotte Erickson, Invisible Immigrants: the Adaptation of English and Scottish Immigrants in 19th Century America (London: Weidenfeld and Nicolson, 1972).

${ }^{23}$ Belich, Paradise Reforged, 137. Arnold, "Some Australasian Aspects of New Zealand Life, 1890-1913," 75. Arnold cites G. G. Hancox and J. Hight, "The Labour Movement and the Strike of 1913 in New Zealand," Economic Journal 24, no. 94 (June 1914): 202.

${ }^{24}$ Marilyn Lake, "1914: Death of a Nation," AHA Presidential Address, to "Conflict in History" the Australian Historical Association 33rd Annual Conference, The University of Queensland, 7 July 2014.

25 Philippa Mein Smith, "New Zealand Federation Commissioners in Australia: One Past, Two Historiographies," Australian Historical Studies 34, no. 122 (October 2003): 305-25. See Melanie Nolan, Review of Philippa Mein Smith and Peter Hempenstall and Shaun Goldfinch, "Remaking the Tasman World,"Australian Historical Studies 41, no. 1 (April 2010): 107-08. Donald Denoon and Phillipa MeinSmith with Marivic Wyndham, A History of Australia, New Zealand and the Pacific (Oxford: Blackwell, 2000).

${ }^{26}$ James Bennett, Rats and Revolutionaries: The Labour Movement in Australia and New Zealand 18901940 (Dunedin: University of Otago Press, 2004).

${ }^{27}$ Rosemary Baird, “Across the Tasman: Narratives of New Zealand Migrants to and from Australia, 196595" (PhD thesis, University of Canterbury, 2012). Again, for the later period, see Paul Hamer, Mãori in Australia: Ngā i Te Ao Moemoeā (Wellington: Te Puni Korkiri, 2007), and Alison E. Green, "New Zealand Migrants to Australia: Social Construction of Migrant Identity" (PhD thesis, Bond University, 2006).

${ }^{28}$ Daniel T. Rodgers. Atlantic Crossings: Social Politics in a Progressive Age (Cambridge and London: Belknap Press of Harvard University, 1998).

${ }^{29}$ Olssen published on "the speed with which New Zealand moved to learn from the Australian experience" in "Lands of Sheep and Gold: The Australian Dimension to the New Zealand Past, 1840-1900," in Sinclair, Tasman Relations, 44. For the postwar period, see Melanie Nolan, "Inequality of Luck: Accident Compensation in New Zealand and Australia,” Labour History, no. 104 (May 2013): 191-212.

${ }^{30}$ Jane Tolerton, Ettie: A Life of Ettie Rout (Auckland: Penguin, 1992); Edgar Ross, These Things Shall Be! Bob Ross, Socialist Pioneer, His Life and Times, a Case Study (West Ryde, NSW: Mulavon, 1988); and Journal of New Zealand Studies NS18 (2014), 118-136 
O'Farrell, Harry Holland. They were editors of Maoriland Worker, 1910, 1911-1913 and 1913-1918 respectively.

${ }^{31}$ Michael Sharkey, Apollo in George Street: The Life of David McKee Wright (Sydney: Puncher and Wattmann, 2012), 23.

${ }^{32}$ See H. E. Holland, Howard Elliott v. the New Zealand Worker: Report of Proceedings in the Magistrates Court of Wellington, Nov. 25, 1924 (Wellington: NZ Worker, 1925).

${ }^{33}$ I thank Len Richardson for discussing this historiographical history with me, correspondence, 13 and 14 July 2014. Noel McLachlan, review in the Times Literary Supplement reviews both O'Farrell's and Fitzhardinge's biographies. In those days the $T L S$ did not name the authors of reviews. But they will now reveal them. He thought Pat understood Harry but plainly did not like him.

${ }^{34}$ Short and long versions of Ian Turner's review of P. J. O'Farrell, Harry Holland, private collection; the short version was published, Historical Studies: Australia and New Zealand 12, no. 45 (October 1965): 139.

${ }^{35}$ Pat O'Farrell to Ian Turner, October 18 1964, private collection.

${ }^{36}$ See J. D. Salmond, New Zealand Labour's Pioneering Days: The History of the Labour Movement in N.Z. from 1840 to 1894 (Auckland: Forward Press, 1950).

${ }^{37}$ Peter Franks, “Australian Influence on the New Zealand Labour Movement, 1870-1920” (paper presented to the Australian Society for the Study of Labour History Conference, Trades Hall, Melbourne, July 1991). See also John E. Martin, "1890: A Turning Point for Labour," in Pioneering New Zealand Labour History, ed. Pat Walsh (Palmerston North: Dunmore Press, 1994), 21-51.

${ }^{38}$ Brian Fitzpatrick and Rowan J. Child, The Seamen's Unions of Australia 1872-1972: A History (Sydney: Seamen's Union of Australia, 1981), 8-9.

${ }^{39}$ Salmond, History of the New Zealand Labour Movement, 53.

${ }^{40}$ West Coast Times, April 11891.

${ }^{41}$ Martin, Tatau Tatau: One Big Union Altogether: the Shearers and the Early Years of the New Zealand Workers' Union (Wellington: New Zealand Workers' Union, 1987), 15-17.

${ }^{42}$ Records of the Eighth Intercolonial Trades Union Congresses (the last two of Australasia), Noel Butlin Archives of Business and Labour, Australian National University, Canberra (NBABL), from several collections including: Victorian Operative Bricklayers' Society, T8; the Tom McDonald Papers, P20; the Ballarat Trades and Labour Council, E97; the Federated Seamen's Union of Australasia-Port Adelaide Branch, P92; Printing Industry Employees' Union of Australia-New South Wales Branch, T39; and the Printing Industry Employees' Union of Australia-Queensland Branch, T51, NBABL. See F. R. E. Mauldon, "The Australasian Council of Trade Unions," Economic Record 4, no. 1 (May 1928):1 107.

${ }^{43}$ New South Wales, Report of the Royal Commission on Strikes (Sydney: Government Printer, 1891).

${ }^{44}$ Trades and Labour Council of New Zealand, Report of Annual Conference held at Christchurch, April 1906 (Auckland: TLC of New Zealand, 1906), 12, 39.

${ }^{45}$ Otago Witness, 10 April 1907.

Journal of New Zealand Studies NS18 (2014), 118-136 
${ }^{46}$ Sir George Grey was to have represented New Zealand at the Seventh Intercolonial Trades and Labour Congress held in Ballarat, Victoria, in April 1891, but at the last moment he was delayed in Adelaide, Otago Daily Times, 6 May 1891.

${ }^{47}$ Henry Demarest Lloyd, A Country Without Strikes: A Visit to the Compulsory Arbitration Court of New Zealand (New York: Doubleday, 1900), 8; Henry Demarest Lloyd, Newest England: Notes of a Democratic Traveller in New Zealand, with Some American Comparisons (New York: Doubleday, 1901), 377.

${ }^{48}$ Barry Gustafson, Labour's Path to Political Independence: The Origins and Establishment of the New Zealand Labour Party 1900-19 (Auckland: Auckland University Press, 1981), 29-30.

49 James Holt, Compulsory Arbitration in New Zealand: The First Forty Years (Auckland: Auckland University Press, 1986), 71-74. Labour Department's record of industrial disputes shows strikes went up from 1 in 1909 to 24 in 1912 involving 5746 workers to 73 in 1913 involving 13,400 workers.

${ }^{50}$ Roth, Trade Unions in New Zealand, 30-36; Erik Olssen, "Some Reflections about the Origins of the 'Red' Federation of Labour 1909-1913," in Common Cause: Essays in Australian and New Zealand Labour History, ed. Eric Fry (Wellington: Allen \& Unwin, 1986), 27-41; and "The 'Red Feds," New Zealand's Heritage 5 (1973): 2066-72.

${ }^{51}$ P. J. O'Farrell, "Politics and Coal: The Socialist Vanguard, 1904-08," in Miners and Militants; Politics in Westland, ed. Phillip Ross May (Christchurch: University of Canterbury, 1975), 101-26. Richardson, Coal, Class and Community.

522 October 1908, Minutes of the Committee of Waterside Workers' Federation, Minute Book, 1902-1921, T62/1/1, NBABL; Wanganui Herald, February 201909.

${ }^{53}$ Evening Post, 6 December 1912.

${ }^{54}$ Margo Beasley, Wharfies: a History of the Waterside Workers' Federation (Rushcutters Bay, NSW: Halstead Press in association with the Australian National Maritime Museum, 1996), 36-37.

${ }_{55}^{5}$ May 8 1908, Minutes of the Committee of Waterside Workers' Federation, Minute Book, 1902-1921, T62/1/1, NBABL.

${ }^{56}$ Carina Hickey, "From Coal Pit to Leather Pit: Life Stories of Robert Semple" (PhD thesis, Massey University, 2010), 43-56; Semple had worked as a coalminer in Lithgow, Newcastle, Gippsland and Outtrim (as well as the Coolgardie goldfields), that is NSW, Victoria and Western Australia. When he returned to Newcastle in 1912, for instance, as New Zealand Federation of Labour organizer raising support, he referred to his former union associations in the Newcastle district. Hickey, citing Maoriland Worker (February 23 and April 26 1912) notes that, whilst in Australia in 1912, Semple not only had a "rest" but he had been instructed to solidify ties between New Zealand and Australian coal miners and watersiders, 64.

${ }^{57}$ Bennett, Rats and Revolutionaries, 69.

${ }^{58}$ Edgar Ross, A History of the Miners' Federation of Australia (Sydney: The Australasian Coal and Shale Employees' Federation, 1970), 298-99.

${ }^{59}$ Maoriland Worker, 29 March 1912, see also 10 November 1911, 26 May 1911, 15 September 1911, 4 October 1912. 
${ }^{60}$ Michael Bassett and Michael King, Tomorrow Comes the Song: A Life of Peter Fraser (Auckland: Penguin, 2000), 46. P. H. Hickey, Red Fed: Memoirs (Wellington: NZ Worker, 1925), 53-56.

${ }^{61}$ H. E. Holland, "The Ballot Box"; R. S. Ross, The Tragic Story of the Waihi Strike (Wellington: The Worker, 1913).

${ }^{62}$ L. F. Fitzhardinge, That Fiery Particle, 1862-1914: A Political Biography, William Morris Hughes, vol. 1 (Sydney: Angus and Robertson, 1964); P. J. O'Farrell, Harry Holland, Militant Socialist (Canberra: ANU Press, 1964).

${ }^{63}$ Edna Ryan, Two-Thirds of a Man: Women and Arbitration in New South Wales 1902-08 (Sydney: Hale and Iremonger, 1984), 36, 51-72.

${ }^{64}$ Fitzhardinge, William Morris Hughes.

${ }^{65}$ H. E. Holland to Josiah (Joe) Cocking, 29 February 1910, Diary E (4 December 1909 - 17 May 1920), UON.

${ }^{66}$ Maoriland Worker, 7 February 1912.

${ }^{67}$ Fitzhardinge, William Morris Hughes, 210.

${ }^{68}$ Marlborough Express, “The General Strike,” 11 November 1913; Matarua Ensign, 13 November 1913; Manawatu Standard, 18 November 1913.

${ }^{69}$ Marlborough Express, 5 December 1913; Northern Advocate, 6 December 1913.

${ }^{70}$ The Daily News, 10 November 1913.

${ }^{71}$ Timaru Herald, 1 December 1913.

${ }^{72}$ Ashburton Guardian, 1 December 1913.

${ }^{73}$ Evening Post, 1 December 1913.

${ }^{74}$ Beasley, Wharfies, 36-37.

${ }^{75}$ Worker, 25 December 1913.

${ }^{76}$ The International Socialist, 10 January 1914.

${ }^{77}$ As soon as the New Zealand strike was settled, Hughes was calling for preference to unionists, as a "natural corollary of the settlement of industrial disputes," Evening Post, 27 December 1913.

${ }^{78}$ Evening Post, 15 November 1913; see also Sydney Morning Herald, 8 December 1909.

${ }^{79}$ Timaru Herald \& Ashburton Guardian, 4 December 1913.

${ }^{80}$ Otago Daily Times, 24 January 1914.

${ }^{81}$ Arthur James Cocking, Biography of Josiah Cocking, born $11^{\text {th }}$ May 1867 at Kadina, South Australia. Died 27th July 1960. Aged 93 at Mayfield, NSW, 1989, 22.

http://www.newcastle.edu.au/Resources/Divisions/Academic/Library/Cultural\%20Collections/pdf/jcockin gbio_ocr.pdf.

${ }^{82}$ Josiah Cocking, diaries and notebook papers, Cultural Collections, UON, A7748 to A7754 inclusive (deposited November 1999, in the Archives, Rare Books and Special Collections Unit, now Cultural Collections). The diaries (1884-1960) are online through the Radical Newcastle Project, http://uoncc.wordpress.com/2011/04/01/radical-newcastle-josiah-cocking-papers-online/. See Tony 
Laffan, "Research Note: Josiah Cocking Papers, University of Newcastle," The Hummer 3, no. 7

(Summer 2001-2002).

8331 December 1909, Josiah Cocking, diaries and notebook papers, A7748, UON.

${ }^{84}$ H. E. Holland to Josiah Cocking, 25 August 1914, UON.

${ }^{85}$ Dandelion, "Newcastle Letter," International Socialist Review, 4 December 1909, Josiah Cocking, diaries and notebook papers, UON.

${ }^{86}$ H. E. Holland to Josiah Cocking, 7 November 1911. See also Letter from F. J. Hilman to Josiah Cocking, 24 January 1911. Mrs A. Holland to Josiah Cocking, 17 July 1911, Josiah Cocking, diaries and notebook papers, A7748, UON.

${ }^{87}$ International Socialist Review, 4 December 1909, Josiah Cocking, diaries and notebook papers, UON.

${ }^{88}$ Ibid, 18 December 1909.

${ }^{89}$ New Zealand Herald, 9 December 1913; Fielding Star, 22 December 1913; Lake Wakatipu Mail, 16 December 1913.

${ }^{90}$ North Otago Times, 17 December 1913.

${ }^{91}$ Discussion of cables and replies, see Maoriland Worker, "The Official Report of the New Zealand Strikes,” 21 January 1914. Contemporarily see The Colonist, 8 December 1913.

92 Otago Daily Times, 1, 2, and 8 December 1913; Wanganui Chronicle, 12 December 1913; The Colonist, 8 December 1913.

${ }^{93}$ See, for instance, Grey River Argus and Blackwell News, 11 December 1913, and Hawera \& Normanby Star, 12 December 1913.

${ }^{94}$ Evening Post, 11 December 1913. See Dave McLaren and J. McKenzie's call for labourism rather than revolutionism, Evening Post, 13 February 1914.

${ }^{95}$ Keith Sinclair, A History of New Zealand (Middlesex: Penguin 1969 [1959], 209.

${ }^{96}$ Sun, 6 June 1914.

${ }^{97}$ See discussion of whether New Zealand should be represented at "Australia's Great Labor Congress," Maoriland Worker, 9 February 1921.

${ }^{98}$ H. E. Holland's report on the All-Australian Labor Congress, Maoriland Worker, 20 July 1921.

99 See Maoriland Worker, "Australasian O.B.U.," 8 February 1922, which discussed the OBU in New Zealand compared to the OBU movement in Australia.

${ }^{100}$ Melanie Nolan, "Australasian Assignations? The Impact of the '1890' Generation and the Maritime Strike on later Trans-Tasman Unionism," in Globalisation and Labour in the Pacific: Re-evaluating the 1890 Maritime Strike Symposium Proceedings, eds. Frances Laneyrie and Raymond Markey (Auckland: New Zealand Work and Labour Market Institute, Auckland University of Technology, 2010), 53-68.

Journal of New Zealand Studies NS18 (2014), 118-136 